\title{
Principles of Logistics Applied to Railway Passenger Transport
}

\author{
Martin Vojtek ${ }^{1,{ }^{*}}$, Martin Kendra ${ }^{1}$, Vladislav Zitrický ${ }^{1}$, and Jozef Daniš ${ }^{1}$ \\ ${ }^{1}$ University of Žilina, Faculty of Operation and Economics of Transport and Communications, \\ Department of Railway Transport, Univerzitná 8215/1, 01026 Žilina, Slovakia
}

\begin{abstract}
Main challenge of logistics is delivering right assortment of products in exact amount, to exact place, in exact time, ecologically and for exact price. Logistics deals with freight transport but when the word 'products' is changed to 'passengers', then many principles can be applied to passenger transport. Railway passenger transport is the key part of passenger transport system, so it is necessary to optimize it on logistics philosophy at first.
\end{abstract}

\section{Introduction}

Logistics is defined as an interdisciplinary science, which deals with coordination, harmonisation, connection and optimization of materials, products and services flows including flows of information and financial resources. The main aim is to satisfy needs of the customer with importance of quality aspect and optimal costs [1-4]. Nowadays, logistics become more popular thanks to global trends such as widely opened global market, increasing influence of IT sector and ecological aspects, deregulation, standardization, technical revolution, international migration and industrial society. Majority of logistics research and practical technologies are used in manufacturing enterprises and freight transport but there is a possibility that some modern principles of logistics can be applied in passenger transport [5]. There are some ideas how to apply it specifically in railway passenger transport.

\section{Railway station as a multi-directional cross-docking system}

Classic cross-docking system is the logistics system, where commodities are delivered to the distribution centre and then all commodities are divided in required amount, structure and quality to the specific retail unit. The distribution centre is not used as a warehouse but it is used as a mixing centre [6-8]. Commodities from suppliers are delivered mostly by high-capacity mode of transport for instance railway transport. When some kind of commodity is combined with other commodities to one complete consignment according to customer requirement, than the consignment is sent to the specific customer mostly by freight road transport [9].

* Corresponding author: martin.vojtek@,fpedas.uniza.sk 


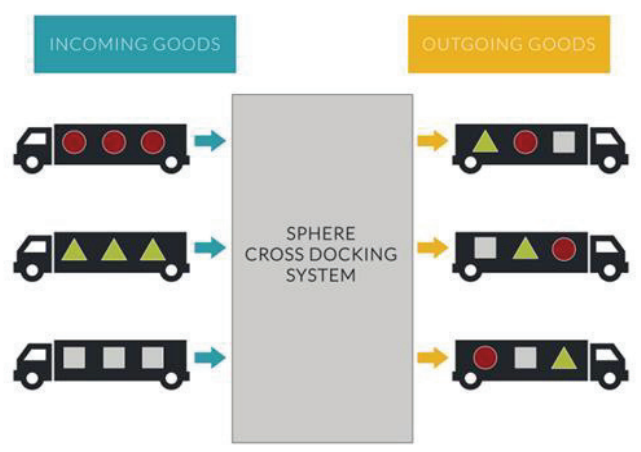

Fig. 1. Classic cross-docking system in freight transport. Source: www.sphereglobal.com.au

Railway passenger station is some kind of transport hub - a starting and finishing point for flows of passengers. Passengers have the opportunity to change the train type from long-haul train to regional train or contrariwise or simply enter or leave the system of railway transport. This is the reason, why it is multi-directional system, not one-way system, as the classic cross-docking system used in freight transport. Main functions of railway passenger stations are:

- ensuring safe, regular and fluent transport,

- ensuring technical and technological services for operators,

- ensuring operation of facilities for traveling public (waiting room, ticket store etc.).

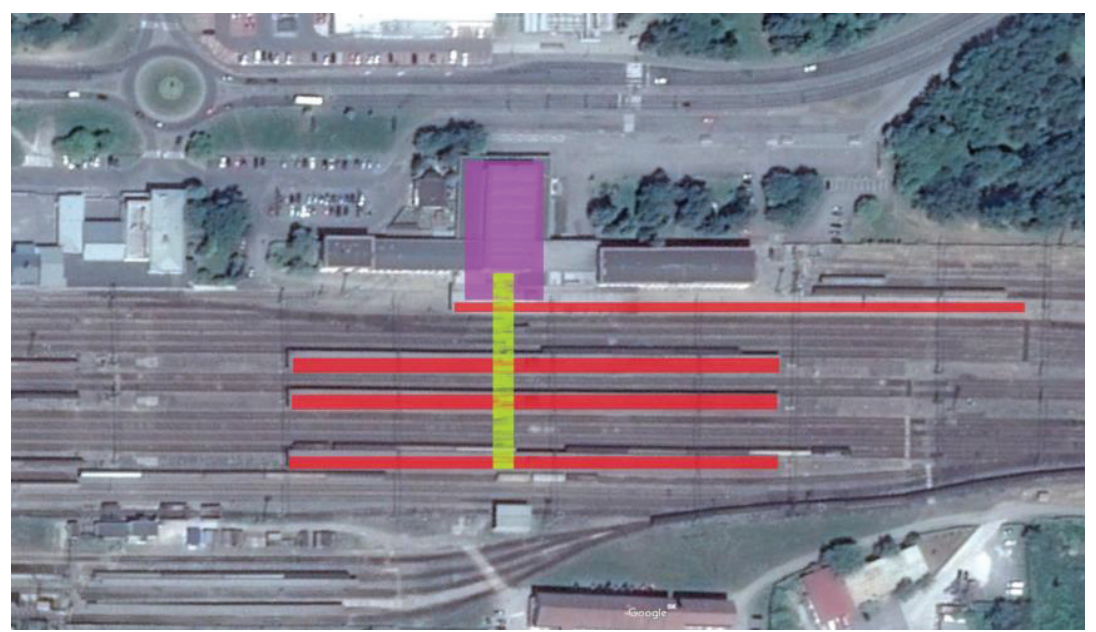

Fig. 2. Zvolen passenger station with marked sectors. Source: authors, base on www.google.sk

In the picture, there are illustrated sectors of real passenger railway station. Purple sector (hall) represents input and output to the system from external systems. Red sector (platforms) represent input and output from internal system consisting of regional and longhaul trains. Green sector (underpass) connects all inputs and outputs and it represents the place, where flows of passengers are mixing up. 


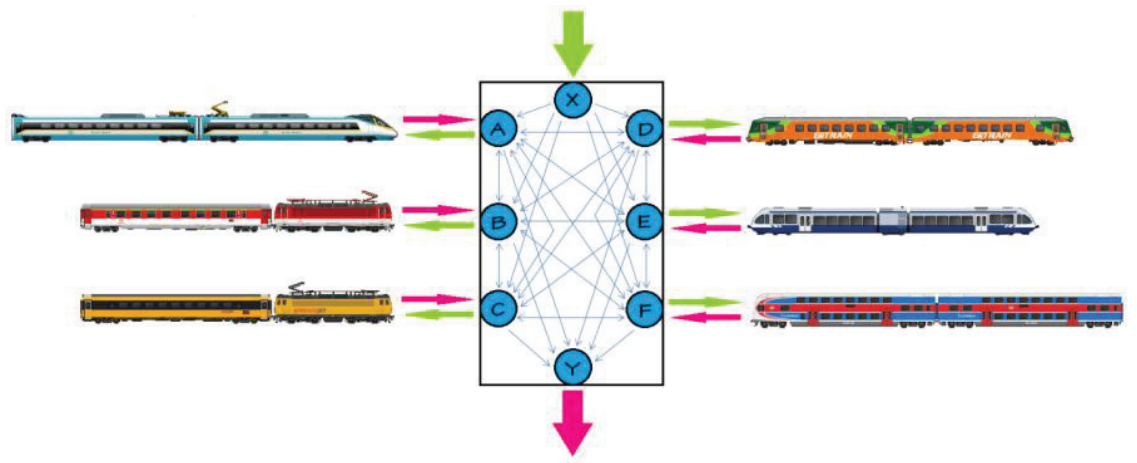

Fig. 3. Simple scheme of cross-docking system applied to railway passenger station. Source: authors

In the picture, there are illustrated flows of passengers between trains which arrive from different directions and depart to different destinations. Points A, B, C, D, E and F represent trains whereas point $\mathrm{X}$ represents input to the transport system and point $\mathrm{Y}$ represents output from the transport system where passengers use another mode of transport instead of railway transport. Classic cross-docking system is substituted by multidirectional cross-docking system and external input and output are added, but the main character of this logistics system is preserved, because passengers are mixed up and their routing can be changed according to their will and requirements.

\section{Terminal of integrated passenger transport as a part of the Hub-and-Spoke technology}

Simple Point-to-Point model of delivering goods means that there are direct connections between all elements in the system. Goods are delivered from each supplier to each client therefore many vehicles are necessary so the transport costs are higher. This disadvantage is solved by the Hub-and-Spoke model, where one or more elements are transformed into hub - the assembly centre for selected area. All elements in the selected area have direct connections only with the hub and these connections are called spokes. If there is more than one hub in the system, connections between hubs represent the main transport lines in the system [10-15].
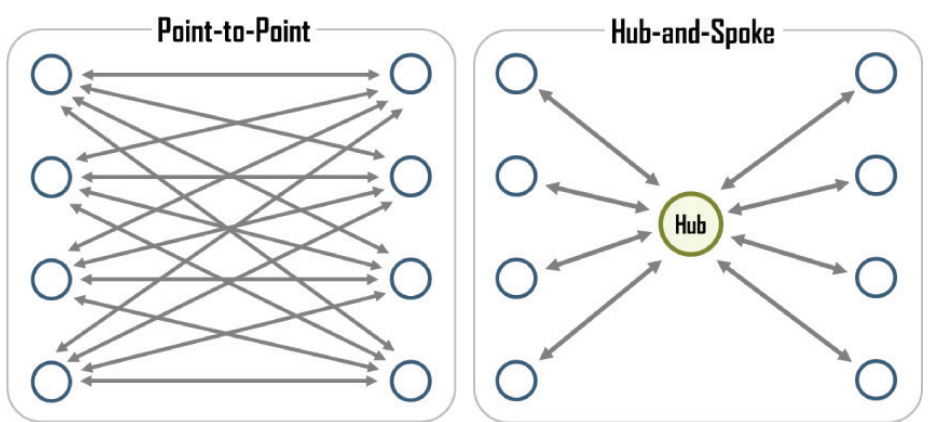

Fig. 4. Comparison of Point-to-Point and Hub-and-Spoke models. Source: [16] 


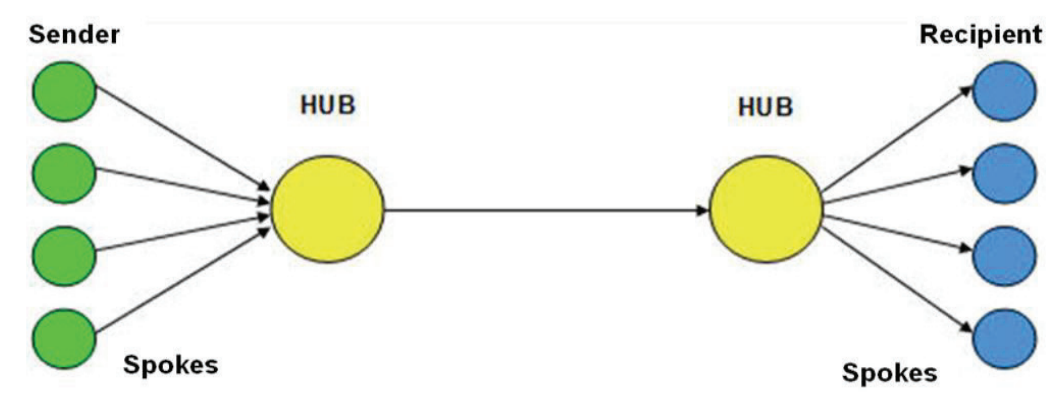

Fig. 5. Scheme of Hub-and-Spoke model with two hubs. Source: [16]

Ideas of the Hub-and-Spoke model are nowadays applied also in passenger transport. In central Europe, there is a modern trend of establishing integrated passenger transport systems in selected regions. Cores of these systems are terminals, where passengers can change vehicle and also the mode of transport, for example get off the bus and get on the train. These terminals are hubs, whence all routes and lines from some region or district are connected. Hub-and-Spoke model is also very common in air transport - airports are hubs and their importance and number of connections usually depending on location and size.

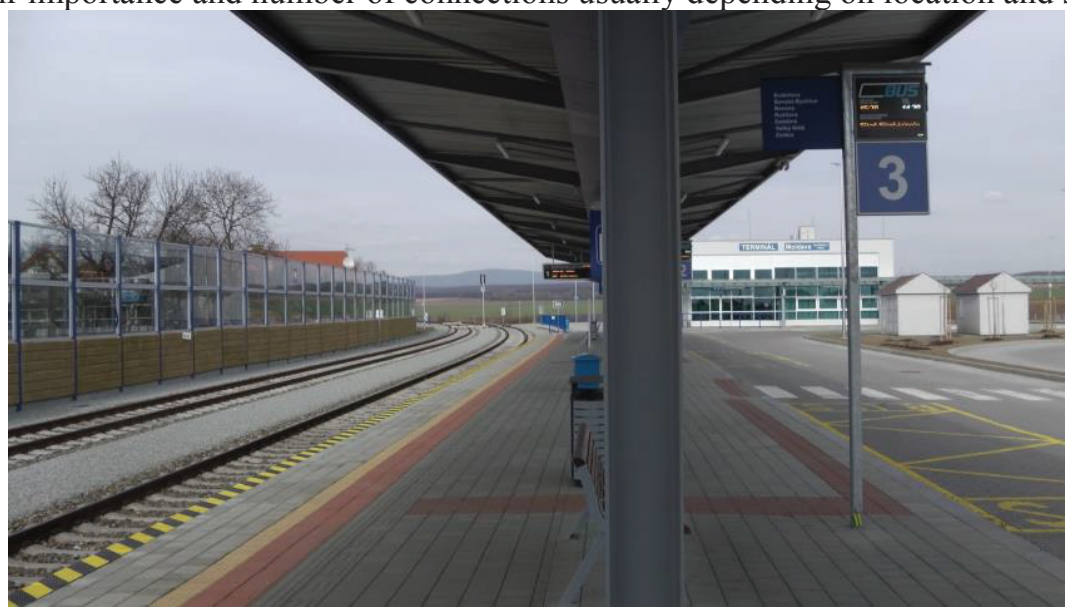

Fig. 6. Terminal of integrated passenger transport in Moldava nad Bodvou, Košice region, Slovakia. Source: [17]

Building these new terminals will improve transport accessibility in the selected region. Operators, who participate in the integrated passenger transport system, are more effective and notice increased demand for transport services. Traveling is easier and passengers can use public transport more often, when they travel regularly to work and school, or occasionally for vacation or other reasons.

\section{Progress of railway passenger transport with using Just-in- Time philosophy}

In general, effectiveness of passenger transport system depends on many factors, such as spatial and temporal accessibility, timetable, connectivity etc. Connectivity of passenger trains and other means of transport can be distinguished also from temporal and spatial point of view. Temporal connectivity is such sequence of arrivals and departures of different passenger trains and other means of transport, which allows changing the different 
passenger vehicles easily in regard to necessary time. Spatial connectivity means the distance between two passenger vehicles, among which the passenger is moving.

Passenger transport is generally considered as an effect of where people are in the exact time and their need to move. The most common reasons for moving are work, education, vacation, sport, cultural events, visiting social and health facilities, meeting family members and friends. One of the main criterions, which are related to the passenger transport, is the time length of transport, which is closely dependent on speed. It does not mean only vehicle speed, because there is also the time of going from home to the station, time for waiting, time for transport and time to reach the finish point. In some case, there is also a time for waiting to another connection, when the passenger change transport vehicles or means of transport.

Application of Just-in-Time ideas can optimize connectivity in railway passenger transport by reduction of transfer time - starting at home and finishing in the transport destination. It is important to synchronize arrivals and departures of all connected trains in all points, where passengers can get on, get off and change the vehicle. Minimizing of waiting time will increase quality of passenger transport in general. Particular emphasis must be put on reliability of all included vehicles, because delays could have serious consequences to the whole system. In freight transport, Just-in-Time technology eliminates needless warehousing, so in passenger transport this means elimination of needless waiting. This can be reached by higher number of trains, buses and other passenger vehicles, which are used in passenger transport system [15, 18-20].

Preconditions of Just-in-Time application in railway passenger transport are [13, 21]:

- dominance of customer (passenger),

- timetable dependent on passengers' needs,

- synchronized arrivals and departures in all point in the transport system,

- harmonised conditions for all operators in the transport system,

- high reliability and punctuality.

Disadvantages of Just-in-Time application in railway passenger transport are:

- overcrowding of transport vehicle may occur,

- increased number of trains could reduce the throughput of railway,

- preference of busses (more flexible).

\section{Conclusion}

Contemporary challenge of logistics is to ensure the connection between offer and demand, so customers would have goods and services available in exact time, exact place and exact quality. Even though logistics is mostly used in industry and freight transport, there are many principles, which can be applied in railway passenger transport and other means of passenger transport. Consecutive development of these ideas can improve quality of passenger transport system in similar way, how it improves freight transport system.

The paper was supported by the VEGA Agency, Grant No. 1/0019/17 "Evaluation of regional rail transport in the context of regional economic potential with a view to effective use of public resources and social costs of transport", at Faculty of Operations and Economics of Transport and Communication, University of Žilina, Slovakia.

This paper is supported by the research project "From horse-drawn railway to intermodal transport" within Visegrad Fund. 


\section{References}

1 R. Kampf, L. Lizbetinova, K. Tislerova, Open Engineering 7, 26-30 (2017), DOI: 10.1515/eng-2017-0006

2 J. Lizbetin, O. Stopka, Open Engineering 6, 441-445 (2016), DOI: 10.1515/eng-20160066

3 J.P. Skrinjar, B. Abramovic, N. Brnjac, Technical Gazette 22, 6, 1617-1621 (2015)

4 J. Gnap, V. Konecny, M. Poliak, Ekonomicky Casopis 54, 668-684 (2006)

5. J. Gasparik, V. Gaborova, V. Luptak, Transport Means - 20th International Scientific Conference on Transport Means, 245-249 (Juodkrante, Lithuania, 2016)

6 A. Dolinayova, M. Loch, M. Kanis, Research in Transportation Economics 54, 33-40 (2015), DOI: 10.1016/j.retrec.2015.10.023

7 V. Molnar, CLC 2013 - Carpath. Logist. Congress, 561-566 (Krakow, Poland, 2014)

8 L. Cerna, B. Bukova, Transbaltica 2015, 377-385 (Procedia Engineering 134, Vilnius, Lithuania, 2016), DOI: 10.1016/j.proeng.2016.01.023

9 J. Lizbetin, L. Bartuska, Transbaltica 2017, 206-211 (Procedia Engineering 187, Vilnius, Lithuania, 2017), DOI: 10.1016/j.proeng.2017.04.366

10 G. Fedorko, V. Molnár, J. Strohmandl, M. Vasil', Transport Means - 19th International Scientific Conference on Transport Means, 466-469 (Kaunas, Lithuania, 2015)

11 J. Gasparik, V. Luptak, P. Mesko, ICTTE - 3rd International Conference on Traffic and Transport Engineering, 388-392 (Belgrade, Serbia, 2016)

12 J. Majerčák, LOGVD 99 - 2nd Scientific Conference with International Participation (Žilina, Slovakia, 1999)

13 J. Sekulová, E. Nedeliaková, Logi - Scientific Journal on Transport and Logistics 6, 2, 79-89 (2015)

14 L. Černá, V. Zitrický, J. Daniš, Open Engineering 7, 1, 6-13 (2017), DOI: 10.1515/eng-2017-0002

15 L. Černá, A. Dolinayová, J. Daniš, Transport Means - 20th International Scientific Conference on Transport Means, 414-419 (Juodkrante, Lithuania, 2016)

16 M. Chovancova, V. Klapita, Transport Means - 20th International Scientific Conference on Transport Means, 112-116 (Juodkrante, Lithuania, 2016)

17 H. Böhme, Krátka návšteva v Košiciach a v Moldave nad Bodvou, Available online: https://www.vlaky.net/zeleznice/spravy/6026-Kratka-navsteva-v-Kosiciach-a-vMoldave-nad-Bodvou/ available on 2017/09/25 (2016)

18. I. Kubasakova, J. Jagelcak, Communications: scientific letters of the University of Žilina 18, 2, 109-112 (2016)

19. Z. Záhumenská, J. Gašparík, 12th International Scientific Conference of Young Scientists on Sustainable, Modern and Safe transport, 976-981 (Procedia Engineering 192, 2017), DOI: 10.1016/j.proeng.2017.06.168

20. J. Gašparík, V. Lendel, Logi - Scientific Journal on Transport and Logistics 1, 1, 3343 (2010)

21. I. Kubasakova, R. Kampf, O. Stopka, Communications: scientific letters of the University of Žilina 16, 2, 9-13 (2014) 